\title{
ЕПІЗООТИЧНА СИТУАЦІЯ ЩОДО ГЕЛЬМІНТОЗІВ ГУСЕЙ У ГОСПОДАРСТВАХ ПОЛТАВСЬКОЇ ОБЛАСТІ
}

\section{Рецензент - кандидат ветеринарних наук О. В. Кручиненко}

За результатами здійснених копроскопічних досліджень гусей різних вікових груп у господарствах Полтавської області (Глобинський, Зіньківський, Полтавський, Машівський, Миргородський, Новосанжарський, Чорнухинський, Чутівський райони) з різною формою власності зареєстровані наступні илунково-кишкові нематодози: амідостомоз (37,6\%), гангулетеракоз (30,37\%), капіляріоз (19,92\%), трихостронгільоз (6,26\%). Встановлено, шуо ступінь ураженості гусей збудниками гельмінтозів залежав від віку, сезону року та форми власності господарств.

Ключові слова: гуси, амідостомоз, гангулетеракоз, капіляріоз, трихостронгільоз, вікова та сезонна динаміки, екстенсивність та інтенсивність інвазіі.

Постановка проблеми. За даними вітчизняних і окремих зарубіжних дослідників, гельмінтози птиці мають широке розповсюдження у господарствах із різною формою власності.

3 метою відновлення й подальшого розвитку в Україні такої високоінтесивної й динамічної галузі, як гусівництво, потрібно забезпечити птицю високоякісними кормами, належними умовами утримання та високим рівнем ветеринарного обслуговування $[2,7,8]$.

Аналіз основних досліджень і публікацій, у яких започатковано розв'язання проблеми. Гельмінтози, зокрема нематодози, залишаються найпоширенішими інвазійними хворобами птиці. Їх збудники домінують у паразитоценозах.

Так, у Тюменській області в результаті досліджень встановлено, що гуси уражені:

нематодами Ganguleterakis dispar $(\mathrm{EI}=80,5 \%)$, Amidostomum anseris $(\mathrm{EI}=42,0 \%)$;

цестодами Drepanidotaenia lanceolata $(\mathrm{EI}=24 \%)$ та трематодами Prosthogonimus ovatus (EI=7,9\%).

Мухаметшин Ільгам зазначає, що в господарствах різних форм власності Передуралля Респу- бліки Башкортостан гуси інвазовані на 86,9\% (трематодами на $14,5 \pm 1,76 \%$, цестодами $30,9 \pm 1,30 \%$, нематодами - 54,5 $\pm 1,41 \%$ ) [5, 6].

За даними вчених, у господарствах Дніпропетровської, Запорізької та Миколаївської областей гельмінтозна інвазія гусей реєструвалась в усі пори року, а екстенсивність інвазії (як у дорослої птиці, так і у молодняка) досягала 100 \% $[3,4]$.

Мета і завдання досліджень. Метою досліджень було вивчення епізоотичної ситуації та видового складу збудників гельмінтозів водоплавної птиці у господарствах Полтавської області з різною формою власності.

У завдання досліджень входило визначення EI та II гельмінтозів водоплавної птиці.

Матеріали і методи досліджень. Дослідження проводили впродовж 2010-2012 років на базі наукової лабораторії кафедри паразитології та ветеринарно-санітарної експертизи Полтавської державної аграрної академії.

Вивчення епізоотичної ситуації 3 шлунковокишкових гельмінтозів гусей проводили у господарствах Полтавської області 3 різною формою власності (Глобинський, Зіньківський, Полтавський, Машівський, Миргородський, Новосанжарський, Чорнухинський, Чутівський райони).

У ході епізоотичного обстеження гусепоголів'я основними показниками були екстенсивність та інтенсивність ураження (EI та II) птиці гельмінтами.

Усього досліджено 1742 голів гусей віком від одного до 24-х місяців горьківської та великої сірої порід.

Фекалії досліджували стандартизованим методом за Г. А. Котельниковим і В. М. Хреновим (1981).

Визначення яєць гельмінтів до виду проводили під мікроскопом при збільшенні х 120 та за допомогою атласу гельмінтів тварин [1].

\footnotetext{
* Науковий керівник-доктор ветеринарних наук, професор В. О. Євстаф'єва
} 
Результати досліджень. За результатами моніторингу епізоотичної ситуації та за наслідками паразитологічних обстежень у господарствах Полтавської області встановлено наявність гельмінтозів. Зареєстровано чотири види шлунково-кишкових нематодозів: Amidostomum anseris (Zeder, 1880), Capillaria anseris (Madsen, 1945), Ganguleterakis dispar (Schrank, 1790), Trichostrongilus tenuis (Mehlis, 1846). Проведені нами копроовоскопічні дослідження виявили, що інвазованість гусепоголів'я, в середньому, становила: амідостомами $(37,6 \%)$, гангулетеракісами $(30,37 \%)$, капіляріями $(19,92 \%)$ та трихостронгілюсами $(6,26 \%)$ (табл. 1).

Згідно 3 даних таблиці 1, екстенсивність нематодозних інвазії гусей у особистих підсобних господарствах Полтавської області була вищою (амідостомоз - 46,8 \%, гангулетеракоз - 42,9 \%, капіляріоз - 22,31\%, трихостронгільоз - 14,98 \%), аніж у спеціалізованих гусегосподарствах (32,24\%, $23,07 \%, 18,53 \%$ та $1,18 \%$ відповідно).

За результатами аналізу епізоотичної ситуації у Зіньківському, Миргородському та Чорнухинському районах щодо інвазійних хвороб гусей встановлено, що ступінь ураження птиці залежав від їх віку (табл. 2).

Так, найбільший відсоток птиці, ураженої амідостомами і гангулетеракісами, реєстрували у 3,5-4-місячних (63,79 і 56,89 \% відповідно), трихостронгілюсами - у 2,5-3-місячних гусенят. Разом із тим пік капіляріозної інвазії відмічали у 10-12-місячної птиці (екстенсивність інвазії становила 13,04 \%).

Вивчення сезонної динаміки шлунковокишкових гельмінтозів водоплавної птиці проводили у господарствах Чорнухинського, Миргородського, Глобинського районів Полтавської області. Встановлено, що ступінь ураженості гусей збудниками шлунково-кишкових нематодозів залежав від сезону року (табл. 3).

Так, пік амідостомозної, гангулетеракозної та трихостронгільозної інвазій у гусей припадав на осінній період року (відповідно, ЕI $=46,51 \%$, $44,96 \%, 17,05 \%)$, а при капіляріозі - взимку $(29,73 \%)$.

Спад екстенсивності трихостронгільозної, амідостомозної та гангулетеракозної інвазій спостерігали у весняний період року (відповідно, $3,31 \%, 12,58 \%$ та 9,27 \%), капіляріозної - влітку $(\mathrm{EI}=13,18 \%)$.

\section{1. Інвазованість гусей шлунково-кишковими нематодозами у господарствах Полтавської області}

\begin{tabular}{|c|c|c|c|c|c|}
\hline Форма власності & Дослідже- & \multicolumn{4}{|c|}{ Екстенсивність інвазії, \% } \\
\cline { 3 - 6 } господарств & но, голів & $\mathrm{A}$ & $\Gamma$ & $\mathrm{K}$ & $\mathrm{T}$ \\
\hline Особисті підсобні господарства & 641 & 46,8 & 42,9 & 22,31 & 14,98 \\
\hline Спеціалізовані гусегосподарства & 1101 & 32,24 & 23,07 & 18,53 & 1,18 \\
\hline Усього & 1742 & 37,6 & 30,37 & 19,92 & 6,26 \\
\hline
\end{tabular}

Примітка: А - амідостомоз, Г - гангулетеракоз, К - капіляріоз, Т - трихостронгільоз

\section{2. Ураэсеність гусей різного віку илунково-кишковими нематодозами} у господарствах Полтавськой області

\begin{tabular}{|c|c|c|c|c|c|}
\hline Вік & Досліджено, & \multicolumn{4}{|c|}{ ЕІ, \% } \\
\cline { 3 - 6 } гусей, міс. & голів & амідостомо3 & гангулетерако3 & капіляріо3 & трихостронгільоз \\
\hline $1,5-2$ & 118 & 32,2 & 26,27 & 5,08 & 2,5 \\
\hline $2,5-3$ & 118 & 45,8 & 47,46 & 11,86 & 7,63 \\
\hline $3,5-4$ & 116 & 63,79 & 56,89 & 10,34 & 6,89 \\
\hline $4,5-5$ & 115 & 54,78 & 53,91 & 11,3 & 3,48 \\
\hline $5,5-6$ & 115 & 46,09 & 38,26 & 8,7 & 3,48 \\
\hline $10-12$ & 115 & 26,9 & 8,7 & 13,04 & 0,86 \\
\hline
\end{tabular}

3. Сезонна динаміка илунково-кишкових нематодозів у господарствах Полтавської області

\begin{tabular}{|c|c|c|c|c|c|}
\hline \multirow{2}{*}{$\begin{array}{c}\text { Сезон } \\
\text { року }\end{array}$} & Досліджено, & \multicolumn{4}{|c|}{ ЕІ, \% } \\
\cline { 3 - 6 } & голів & амідостомо3 & гангулетерако3 & капіляріо3 & трихостронгільо3 \\
\hline Зима & 185 & 24,32 & 20 & 29,73 & 4,32 \\
\hline Весна & 151 & 12,58 & 9,27 & 15,89 & 3,31 \\
\hline Літо & 129 & 39,53 & 37,98 & 13,18 & 10,85 \\
\hline Осінь & 129 & 46,51 & 44,96 & 25,58 & 17,05 \\
\hline
\end{tabular}


СТОРІНКА МОЛОДОГО ВЧЕНОГО

4. ІІ илунково-киикових нематодозів у господарствах Полтавської області залежно від сезону року

\begin{tabular}{|c|c|c|c|c|}
\hline \multirow{2}{*}{ Сезон року } & \multicolumn{4}{|c|}{ II, екз./кр. (М \pm m) } \\
\cline { 2 - 5 } & амідостомо3 & капіляріо3 & гангулетерако3 & трихостронгільоз \\
\hline Зима & $1,72 \pm 0,27$ & $2,88 \pm 083$ & $1,96 \pm 0,36$ & $2,63 \pm 0,8$ \\
\hline Весна & $1,12 \pm 0,3$ & $1,54 \pm 0,14$ & $1,45 \pm 0,17$ & $0,91 \pm 0,1$ \\
\hline Літо & $2,49 \pm 0,39$ & $2,66 \pm 0,87$ & $1,72 \pm 0,34$ & $1,13 \pm 0,39$ \\
\hline Осінь & $3,24 \pm 0,44$ & $3,15 \pm 0,56$ & $3,8 \pm 0,45$ & $3,3 \pm 0,41$ \\
\hline
\end{tabular}

У ході вивчення II $\mathrm{y}$ інвазованих гусей (табл. 4) максимальну кількість яєць нематод знаходили восени $(3,8 \pm 0,45$ екз./кр.). Навесні інтенсивність шлунково-кишкових гельмінтозів знижувалася до 0,91 $\pm 0,1$ екз./кр.

Висновки:

1. Встановлено, що найбільш поширеними інвазіями шлунково-кишкового тракту гусей у господарствах Полтавської області 3 різною

\section{БІБЛІОГРАФІЯ}

1. Атлас гельмінтів тварин / [Дахно I. С., Березовський А. В., Галат В. Ф. [та ін.] - К. : Ветінформ, 2001. - $118 \mathrm{c}$.

2. Богач M. В. Залежність показника екстенсивності інвазійних захворювань кишкового тракту індиків від віку птиці / М. В. Богач // Ветеринарна медицина: Міжвід. темат. наук. зб. - X., 2004. - № 84. - С. 104-106.

3. Короленко Л. Моніторинг гельмінтозів водоплавної птиці в господарствах степової зони України та лікувально-профілактичні заходи / Л. Короленко // Ветеринарна медицина України. - 2008. - №1. - С. 27-29.

4. Короленко Л. Моніторинг гельмінтозів та еймеріозів свійської птиці / Л. Короленко // Ветеринарна медицина України. - 2010 - №7. C. 14-16.

5. Мухаметшин И. А. Смешанные инвазии гусей и кур в хозяйствах Предуралья Республики Башкортостан профилактика: автореф. дис. ... канд. биол. наук: 03.00.19 «Паразитология, гельминтология».- Уфа, 2004. - 23 с. - Режим доступа: формою власності є: амідостомоз, гангулетеракоз, капіляріоз та трихостронгільоз.

2. Середня інвазованість гусепоголів'я становила: амідостомозом - 37,6 \%, гангулетеракозом - 30,37 \%, капіляріозом - 19,92 \%, трихостронгільозом - 6,26\%.

3. EI та II гельмінтозами залежить від віку птиці, сезону року та форми власності господарств.

http://www.referun.com/n/smeshannye-invaziigusey-i-kur-v-hozyaystvah-preduralya-respublikibashkortostan.

6. Сергушин A. B. Терапия и профилактика ассоциативных инвазий гусей в хозяйствах Тюменской области: автореф. дис. ... канд. вет. наук: 03.00.19 «Паразитология, гельминтология». Тюмень, 2000. - 23 с. - Режим доступа: http://hfawildcats.com/invazionniye-bolyeznigusyey-yuga-tyumyenskoy-oblasti/

7. F. H. M. Species of the nematode genus Amidostomum Railliet and Henry, 1909 in aquatic birds in the Netherlands / F. H. M. Borgsteede, K. M. Kavetska, P. E. F. Zoun // Helminthologia. Volume 43, № 2. - Р. 98-102. - Режим доступу: http://www.springerlink.com/content/x413r2664417 $7661 /$

8. Zuchowska E. Helminth fauna Anseriformes (Aves) in the Lodz Zoological Garden / E. Zuchowska // Wiad Parazytol. - 1997 - №43 (2). P. 213-215. - Режим доступу: www.ncbi.nlm. nih.gov/pubmed/9424942 